18. Z. O. Serebryakova. The phenomenon of deinstitutionalization of modern Russian journalism as a subject of sociological research. Doctoral thesis. Nizhny Novgorod (2017).

19. A. A. Yefanov. Falling confidence in television: a sociological view of the problem. B. South Ural State U. S: Soc. Scien. Hum., 18 (2) (2018), pp. 89-94, $10.14529 / \mathrm{ssh} 180214$

20. I. M. Dzyaloshinsky, A.V. Sharikov. On the current state and further development of the sphere of communication sciences in Russia. MediaScope, 3 (2017), p. 3.

DOI 10.15826/B978-5-7996-3081-2.36

\title{
"New Journalism" as a Synthesis of Forms: Relationships With Literature, Fiction Publicistics and Screen Documentary
}

\author{
Myasnikova Marina', Martsevich Yury ${ }^{2}$ \\ ${ }^{1}$ Ural Federal University, Ekaterinburg, Russia \\ ${ }^{2}$ IntCom, Ekaterinburg, Russia \\ Corresponding author: Myasnikova Marina, avt89@yandex.ru
}

Abstract. The phenomenon of "new journalism" is studied, which is a hybrid form of creativity that arose at the intersection of journalism and literature, and we consider it in connection with not only "literature of fact" in broad sense (non-fiction), but also separately with newspaper and magazine fiction publicistics and screen documentary, which includes documentary films and documentary and publicistic and sensational entertainment TV programs. Similarities, differences and effects of two types of media narrative - verbal and audiovisual - are established on the material of T. Capote's novel "In Cold Blood", domestic court essays, documentaries - "Supreme Court" of H. Franc and "Into the Abyss. A Tale of Death, a Tale of Life" of W. Herzog, as well as modern crime-law TV shows. The specified content is united by a specific genre of "true crime."

Keywords: "new journalism", non-fiction, true crime, fiction publicistics, essay, documentary filmmaking 


\section{Introduction}

In the 60 s of the last century, an original style trend emerged in the US newspaper practice, which soon became known as "new journalism", the main genre of which was called non-fiction, and a characteristic feature - the joint use of techniques of fiction and journalism. Later on, this direction became a noticeable trend in the world cultural context and today has gained incredible popularity. In many countries, literature non-fiction is published in large circulation, book fairs are held, prizes are awarded.

At the same time, the American experience, which influenced the work of many writers in the world, can hardly be considered unique. It grew out of the gigantic world experience accumulated by mankind over several centuries. As for the research of the style direction "new journalism", today we see a great interest in it from the science - both foreign and domestic. In the XXI century, many scientific works were published. Well known works of N. Sims and M. Kramer [Sims, Kramer, 1995], J. Hartsock [Hartsock, 2000], R.S. Boynton, [Boynton, 2000]. As Novoselova points out, the USA produces a large number of manuals with recommendations for writing non-fiction prose in the spirit of "new journalism" [Novoselova, 2017], such as the books by Lee Gutkind [Gutkind, 2012], M. Kramer, and V. Call [Kramer, Call, 2007], J. Hart [Hart, 2011]. We can also name authors in Russia as A. Gvozdev [2007], D. Kharitonov [2010], O. Nesmelova and J. Konovalova [2011], V. Khorolsky [2012], Kazakova [2016], Savelyeva [2018], D. Vorobyova [2019], and others.

The purpose of this article is to study domestic and foreign scientific literature on the phenomenon of "new journalism" in the USA, to consider the features of domestic experience of exploring the space "between", "at the junction" or "within the synthesis" of literature and journalism. The issue is not fully clarified both in terms of terminology and practice. Some scholars suggest "to combine foreign and domestic approaches in interpreting these concepts and to define non-fiction literature as a hybrid, synthetic meta-genre of narrative story, "at the intersection" between literature and journalism" [Savel'eva, 2018, 90]. Others see this phenomenon both as a phenomenon of journalism and as a literary school. Still others understand this hybrid phenomenon lopsided, from one side or the other, without achieving a holistic understanding of the creative world of the work. They either apply literary analysis, mechanically listing journalistic techniques, or assess the publicistic significance of the text, identifying artistic techniques. That is, 
some apply the genres of non-fiction exclusively to literature. Others - only to journalism. Fourth discover cinematic elements in non-fiction literature. Fifth carry out a comparative analysis of two types of media narrative verbal and audiovisual - on the material of literary non-fiction and documentary films. Sixth propose to apply the interdisciplinary principle of study to balance the extremes. One way or another, "there is still no consensus on the genre affiliation of "hybrid" works, no mechanisms for analyzing such works have been developed... No time frame has been defined, nor the criteria for attributing certain works to this direction" [Nesmelova, Konovalova]. That's why the topic of this article seems relevant to us.

\section{Theory, methodology, practice}

\subsection{Basic concepts}

"New journalism", which emerged in the USA in the 60s of the last century is seen as a certain direction in literature, non-fiction is a genre group of works, and true crime is a thematic variety within a given group. The canon of the true crime genre included detailed portraits of real people, reconstruction of the crime scene, building a chronology of previous and subsequent events, analysis of police and court procedures, scientific interpretation of psychological motives of the criminal.

The concept of non-fiction itself, being a literature of fact rather than fiction, is sometimes interpreted too expansively as a form of documentary, non-fictional literature, to which narrative texts can also belong: literary adapted biographies, travelogues, popular scientific works, journalistic materials, and non-narrative: dictionaries, reference books, exploitation manuals, life textbooks, etc. Therefore, the term "narrative non-fiction" has been used more and more recently, which in our domestic version sounds like "narrative literature of fact" often replaced by numerous definitions: "fiction-documentary literature", "documentary prose", "prose without fiction", "documentary literature", "fiction documentary". At the same time, the question of establishing kinship ties of "fiction and documentary literature (non-fiction) and so-called "fiction publicistics", which has long existed in our national tradition, remains unclarified. Although, in our view, these ties are obvious. We agree with A. Pronin [Estetika zhurnalistiki, 2018, 94], believing that the English name "narrative non-fiction" is just right for the term "narrative publicistics" because it allows, while maintaining the integrity of understanding the creative world of the work, overcome the one-sidedness of either literary or journalistic analysis. 


\subsection{Research Methods}

When writing the article, general scientific and special-scientific research methods were used: analysis, synthesis, analogy, comparison, which made it possible to clarify some theoretical provisions related to the topic being developed. And also an interdisciplinary approach was applied, which means combining the efforts of representatives of different sciences, "around a single object - a publicistic narrative as a special method and result of the subjective author's construction of an integral story about non-fictional events according to the laws of artistic narration" [Estetika zhurnalistiki, 2018, 94]. A. Pronin writes about this method, mentioning literary criticism, linguistics, journalism. We suggest adding film and television theory to this collection.

\subsection{Features and prerequisites of the emergence of "new journalism"}

It is commonly known that the most prominent representatives of the "new journalism" in the USA were Truman Capote, Hunter Thompson, Norman Mailer, Tom Wolfe, two of whom were writers, and two were journalists. In 1973, Wolfe published the New Journalism manifesto, accompanying his text with an "Anthology of New Journalism", which included 28 works by 23 American writers. In Russia it was translated only in 2008. The "Anthology" emphasized that this narrative form, with its characteristic style, did not originate in the form of "novels-reportage", as Capote outlined its genre, but from the depths of newspaper practice. It was this fact that Wolfe viewed as something out of the ordinary, because he worked in the newspaper himself.

He noticed the emergence of a new style back in 1962 (earlier than the release of Capote's novel "In Cold Blood") in a text by "Times" reporter Gay Talese "Joe Louis - King in his prime", published in "Esquire" magazine. Wolfe was struck by the unexpected discovery: it turns out "newspaper-magazine articles can be written so that... they can be read like a novel" [Novaya zhurnalistika i Antologiya, 2008]. The first magazine article by Wolfe himself, published in the Sunday supplement "New York" of the newspaper "Herald Tribune", was also read as a story, despite the scenes and dialogues written off from life. The author joined the game by appearing in essays; he wrote about himself as an observer in the third person; looked from someone else's point of view in his texts; immersed into the stream of consciousness of the characters; imitated their intonation; conveyed dialogues and internal monologues, allowing the reader to speak with the characters through the narrator; changed the angles of the image in the descriptions 
of the places of action; not only truthfully described what was happening, but also showed the personal or spiritual life of the characters. To do this, Wolfe made extensive use of punctuation and printing. In the midst of all these events, the incredibly famous novel by Truman Capote "In Cold Blood" appeared, which is associated with the subgenre true crime. The author himself did not attribute it to journalism, calling it a "reportage novel" or a "non-fiction novel". But according to Wolfe, "thanks to this, the new journalism, as it was soon called, received another strong impulse" [Novaya zhurnalistika i Antologiya, 2008]. Truman Capote's book "In Cold Blood" was a vivid experiment that demonstrated the author's ability to compose almost as spectacularly as life itself.

The late 1950s in the United States were noted, as Wolfe writes in his "Anthology", by a disease common at that time. "Its main symptom is an irrepressible desire to plunge into the "real world" [Novaya zhurnalistika i Antologiya, 2008]. By the way, the same aspiration explains rise in our country (both in the early 1960s, at the height of the "years of the Thaw", and at the end of the 1980s, at the beginning of the "perestroika") of screen documentaries, every time became vivid visual reflection of the publicistic heat of everyday life. M. Novoselova points out the reasons for the emergence of "new journalism" in the verbal version of the media narrative: "among the factors that led to the convergence of journalism and literature in 1960-70s there are variability, catastrophism, fantasticity of life itself that outstrips imagination; the impact of scientific and technological revolution, precise methods of cognition; competition of literature with the media; desire to create a true picture of the world" [Novoselova, 2017, 46-47]. Thanks to their style, the authors of new forms managed to record the actual events that worried people at that time, and these forms reflected not only the epochal, but also the temporary, everyday: crimes, racial problems, subcultures, wars, finance. A hallmark of "new journalism" was subjectivism, which manifested itself in complicity and creating a presence effect. "New journalists" made it possible for different representatives of society to express their opinions, pushing back the "official point of view" [Novoselova, 2017, 47]. This, by the way, reminds us of our modernity, in which the so-called "citizen journalism", which relies on real momentary observations of the events of a fast-moving life, often no less fascinatingly described than fictional ones, is widely developed. Another reason for the rise of "new journalism" in the 1960s was the degradation of the modern American novel, its departure 
from the problems of modernity. Novelists got carried away with "myth" and "magic". Journalists were inspired by the work of great realist writers of the past, including European, such as Balzac, and Russians like Gogol, able to immerse the reader in the material, emotionally captivate and capture him. In our country, a surge of non-fiction was observed at first "in the perestroika years, when lectures of historians gathered thousands of audience, and the publicitics had enormous circulation. In the 1990s non-fiction was "washed away" by a wave of Western fiction (including fantasy), which rushed to the Russian market" [Kazakova, 2016, 9]. In recent years non-fiction has returned to compensate for the fictionalization of modern life and to comprehend real events.

\section{4. "Non-fiction" and "fiction publicistics"}

Journalist Valeriy Agranovskiy, paying attention to the rise of interest in non-fiction in our country, also formulated the prerequisites of this phenomenon. First, since the reader became more educated, he could already understand many things himself, he needed only information. Secondly, the scientific and technological revolution contributed to the development of means of communication, which made it possible to accurately record events, which devalued fantasy. Thirdly, if the former realism was a "realism of similarity", the current one acquired the features of genuine documentalism. Fourthly, "the reader to some extent "got hungry" for diaries and documentary testimonies about times and historical events that are little-known and once even hidden" [Agranovskij, 1978]. They wanted to know their past better.

It's commonly believed that the continuators of traditions of large forms of "new journalism" in our country were writers E. Limonov, A. Kabakov, Nobel Prize Winner S. Aleksievich, who, at the same time, relied on the canon of past times (Defo, Gogol, Dostoevsky), and on domestic samples (in particular, "Brest Fortress" by Sergei Smirnov, "Soldiers' Memoirs" by K. Simonov), "The Siege Book" by Ales Adamovich and Daniil Granin), documentary chronicles based on the testimonies of participants in the events painstakingly collected and recorded by the authors Great Patriotic War - defenders of the Brest Fortress, soldiers of the Great Patriotic War, survivors of the Siege of Leningrad. Chronicles of S. Smirnov, by the way, existed not only in writing, but also on screen in the form of his cyclical author's television program. And Svetlana Aleksievich created her "search" genre, which did not receive the final name - "novel of voices", or "synthetic biography." Other definitions 
of her works, conveying the polyphonic character of the new genre, sound like "epical-choral prose, roman-oratorio, cathedral novel", etc. [Desyukevich].

At the same time, the appearance of "novels-reports", or "novels-interviews", close to the traditions of "new journalism" in the USA, was preceded, as we believe, by our domestic practice of certain forms of verbal language related to the genre true crime (including the rich experience of the Soviet judicial essay) and the rapid development of screen documentaries from the 1960s-1990s. As for the essay, the literature about it in Russian science is extensive and diverse, although today it is very little in demand in both print and online publications. However, its contribution to the development of the true crime genre is obvious and worthy of study. The experience of the Soviet judicial essay differs clearly in the better way compared to the practice of domestic television related to programs on criminal topics.

In the Russian science of mass media, forensic essay is considered a genre of publicistics. And the concept of "publicistics" is usually defined as a type of activity, method of creativity and variety of works along with information journalism and analytical publicistics. We consider these three activities through the concept of "fact", arguing that information journalism is based on a single fact, at the heart of analytical publicistics there is a quantitative accumulation of facts forming an opinion, and in the basis of fiction publicistics there is a qualitative transformation of fact, leading to the birth of an artistic image. It is natural to assume that the essay is a genre of fiction publicistics. And as we said above, referring to the opinion of A. Pronin, the term "narrative non-fiction" is more close to the term "narrative publicistics" than any other term, which is similar in content to "fiction publicistics", which, as well as the method underlying the "narrative non-fiction", allows constructing stories about real events through artistic imagery, moving away from the mechanical connection elements of journalism and literature as holistic structures. And this means that our traditional "fiction publicitics" as well as "narrative non-fiction" should be understood not as a hybrid of journalism and literature, existing as independent forms of creative activity, but as a combination within a single narrative structure of two equal components - the life foundation and artistic way of mastering reality.

One way or another, but it follows that the essay does not exist within the framework of literature or journalism, or both of them together (because these are different structures), but in the territory of quite independent type of creative activity, referred to as fiction publicistics. The essay combines only 
separate features of these two activities. Without moving into the territory of either, it retells authentic (life) stories by artistic means. And the means traditionally used by our domestic essay genre (which are written about by our researchers) and American non-fiction in the framework of "new journalism" are largely the same. The kinship between the two is obvious. In the essay as an artistic and publicistic genre one can find many features of non-fiction.

Tom Wolfe defended the method of long-term observation inherent to "new journalism", the need to immerse the author in the material and even in the stream of consciousness of his hero. The contemporary researchers observe the same trait in Russian fiction publicistics. Wolfe pointed out that his colleagues always sought to see everything with their own eyes. Krasnov writes about this feature of fiction publicistics as follows: "To the power of art and thought of the author the strength of the eyewitness, and even better — the direct participant of events is added" [Krasnov, 2006]. The same researcher states that life is always more diverse than any composition. It is interesting, this trait is observed in the most characteristic work of the genre non-fiction - Capote's "In Cold Blood". D. Bykov draws attention to this, recalling that the victim of the crime Clutter "on the day of his death he insured his life! - a detail that only life could invent, a strong author who is not afraid of bad taste" [Bykov, 2015]. As we remember, Capote deliberately violated the chronology of events. Krasnov discovers this trait in the practice of Russian publicistics. This researcher insists on presenting the essayist with the highest requirements to the degree of artistry of recreating reality, arguing with the well-known judgment of Zhurbina about the "sketchiness" of the essay writing.

It is important to note that in our domestic judicial essay the issue of professional responsibility of the writer and moral evaluation of the crime always stood first place. But Capote, as D. Bykov noted, "wrote not for the sake of sociological or moral... conclusion... He wrote, as always, for the sake of feeling, condition. And this state - a delight and horror of the hideousness and harmony of the world, the sorrow in a clear morning among the gold fields of Kansas and the red Indian grass - is generated again by a purely literary method, which not every reader is aware of: it is a contrast between monstrous material and perfect, neat, icy writing" [Bykov, 2015]. However, although Capote denied moralizing, he had a firm position: he opposed the death penalty as "legalized sadism". Moral assessments were extremely important for the "new journalists". Essentially "T. Wolfe has initiated a movement for honest journalism that combines journalism, science, lit- 
erature and testimonies of ordinary citizens. Justice as an ideal was as if rediscovered and proclaimed in the publicistics of Western "new journalists", and this gave the basis for critics to talk about neo-humanism in journalism" [Horol'skij, 2012, 148]. For the authors of our domestic judicial essays, the most important thing was not the course of the investigation and not the form of presentation of the material, but the moral and ethical assessment of situations and people. These are intellectually and emotionally rich essays by Olga Tchaikovskaya, Inna Rudenko, Igor Gamayunov, Anatoliy Rubinov, Arkadiy Vaksberg, Ilya Fonyakov.

2.5. TV version of the genre "true crime"

Another factor that influenced the development of literature and journalism (albeit from the opposite) was television in the early 60s of the last century, becoming their main opponent. According to audience surveys as early as 1963, it was recognized as the main mass media in the USA. Literature and journalism had to urgently look for ways to fight the young rival, whom M. McLuhan figuratively and, as always, paradoxically called a "shy giant." It was the genre of non-fiction that became a response to the claims to success of the audience on the part of television, which was confused at that time. "New journalists" sought to make their texts entertaining: they used techniques of "aesthetic game", irony, excited readers intellectually and emotionally. Being an "aesthete" from literature, Capote wrote his "In Cold Blood" with "metallic brilliance" and essentially created the genre of true crime. Moreover, Capote's novel pointed out the path of development for the screen variants of the genre he opened. Incidentally, Konovalova found in his novel a combination of not only literary and journalistic traits, but also cinematic features such as: "widespread use of parallel and consistent installation, techniques of changing plans and panoramic shooting, free handling of artistic space and time, special role of visual and sound images" [Konovalova, 2013, 205]. The researcher drew attention to the brevity of the descriptions, which brought the book closer to the form of the film script; complexity of compositional construction; intentional violation of the chronology of the presentation of events; techniques of retrospective and, conversely, predictions of the future, etc.

In the future, television itself began to actively cultivate the genre of true crime, which fascinated viewers and raised ratings. At the beginning, it poorly distinguished the good cycles of criminal programs and low-quality crafts. However, in the new century, documentary TV series have flourished on 
television screens in lush colors, they have already relied on strong drama, archetypical images, free construction, open finals. Since then, the stories of real crimes have become an integral part of the narrative tradition of both verbal and screen cultures.

As for television in Russia, it has been particularly active in the development of crime stories since the early 1990s. And unfortunately, it can't stop until now. Researchers point to the transformation of the true crime genre over time. Its origins are generally sought in judicial pamphlets, common in Europe as early as the dawn of the New Time, around the 16th century. Qualitative leap in criminal narrative occurred in the middle of the 20th century. A visual narrative was added to the verbal. The stories of real crimes, previously serving as primary sources for fiction movies based on real events, began to turn into subjects for documentary TV shows and films of different quality. Researchers see the severity of the problem in the fact that the works of this genre, combining reality and fiction, credibility and sensationality fall not only in the field of cultural science, but also in the field of ethics.

2.6. The genre of "true crime" in documentary filmmaking

It is important to note that in our domestic judicial essays of the second half of the last century moral and ethical problems were traditionally the main ones. The same is noted in the best samples of documentary filmmaking. For the author of the film "Supreme Court" (1987), Riga Soviet director Herz Frank it was necessary to immerse in the mysteries of the human soul. Here again, television played its special role (from the opposite). Researchers notice that with its rapid development in the early 60 s of the last century, all previously popular documentary genres, such as journalism, chronicles, propaganda, have moved to home screens, while cinemas became interested in poetic, experimental developments. In these years problematic documentary films are made by real masters: Pavel Kogan, Mikhail Romm, Boris Galanter, Herz Frank, Igor Belyaev, Samariy Zelikin, Vladimir Rotenberg. Herewith the basis of their paintings becomes life itself. Many films of H. Frank grew out of newspaper reporting, as at one time he worked at the evening newspaper, writing and photographing, and his first films were listed as broadcasts for television. After receiving legal education and being a newspaper correspondent, he went to court sessions, filmed a criminal chronicle. He has always had a passion for collecting documents. Impressions accumulated, taking the form of newspaper essays, and over time - films. For 
him, the luck of the documentary filmmaker was not only to make a certain harmony out of the scraps of life, but also to discover the philosophy inside.

However, the audience, unfortunately, still continues to consider documentary filmmaking as propaganda and journalism. And the real documentary filmmaking is either ignored or cannot be seen. The documentary film does not have a rental. It is present only at festivals. As well as the film of Herz Frank "Supreme Court", designated by him modestly "film materials", but representing, as they wrote, "confession before execution" or "physiognomic sketch of the murderer against a social-psychological background of a society life", having direct relation to genre of true crime, became famous, largely due to the fact that it received the Grand Prix of the first All-Union Festival of non-fiction cinema "Russia", which has been held in Ekaterinburg for over 30 years in the status of the main Russian festival of documentary cinema.

The film of H. Frank was about the murder of two people by a 24-yearold student on a domestic basis. The offender is in prison awaiting the death penalty, which is committed in the final. The same, incidentally, happens in the film by German director Werner Herzog "Into the Abyss: A Tale of Death, a Tale of Life" [2011].

Both directors come to the ward to the criminals, but not for the sake of detective investigation of the threads of the case. For them, in the first place is the study not so much of social corruption as the "corruption of the human soul," the soul of their hero. As H. Frank later said, "I was fascinated by the path to repentance... And the film is about this, not about the fact that "a student killed a woman" because of a shortage of jeans..." [Frank, 2004]. Naturally, there is a parallel here with Dostoevsky's work (where in the center of everything that happens is the idea of repentance, and not just physical punishment), as was the case, for example, in T. Dreiser's novel "An American Tragedy".

As Neya Zorkaya wrote, "Frank spends hours and days with the killer, seeking to penetrate the truth of the soul" [Zorkaya, 1991, 36]. Let's remember: "new journalists" did the same, using methods of long observation and immersion, varying the scope of the image, rhythmic alternation of static and dynamic, common and close-ups. Moreover, both of them did this not to savor the bloody scenes, which is typical for tabloid publications and entertainment films. Wolfe also noted this about "new journalists." Herz Frank's film is also complex of expertly constructed narrative, of masterfully compared facts, with a minimum of author's comment and no didactics. 
Close to this method is the German director Werner Herzog, who, in his aforementioned documentary film, like Frank, also revealed to the viewer the entire process of execution of the young murderer sentenced to death. Both directors capture the terrible details of what is happening. In Frank's film, we see the preparation of a criminal for execution: "he is dressed in special clothes of a suicide assassin, shaved off his hair, mustache..." [Zorkaya, 1991, 36], depriving him of his individual human appearance. Herzog demonstrates on screen the murder weapon, the place where the sentenced person is given lethal injection. The details are shocking, but it is more important for directors to show the steps of "spiritual cleansing" that a man condemned to death passes before us. As H. Frank himself said, his film was composed step by step, intuitively. He did not excuse his hero, "but certainly sympathized with his suffering and gave him the opportunity to speak out before his death" [Frank, 2004]. Herzog did the same. The difference from the literary narrative consisted in the visuality of documentary filmmaking. In this regard, Frank asserted: “... you should not spy through the keyhole - you have to look. Watch and see! Through eyes and heart” [Frank, 2004].

At the same time, it seemed to the master that he "exposed someone else's soul too much." Let us recall the same desire of the "new journalists" to show the personal or spiritual life of the characters. Wolfe admitted at the same time: "I and my friends were even accused of "intruding into the inner world of a person" [Novaya Zhurnalistika i Antologiya, 2008]. Significantly, both Herzog and Frank reflected on the wrongfulness and moral cost of the death penalty. Herz Frank's film even gave impetus to the discourse about abolishing the institute of capital punishment in the USSR. In doing so, the director avoids political relevance in the bad sense of the word, "he makes films about what is relevant yesterday, today and for many years tomorrow" [Frank, 2004], as he used to say himself. Wolfe at one time also wrote about the "timeless nature of the theme" of Capote's novel. As we can see, here too, we find the closeness of the artistic directions we consider, united by the term non-fiction.

N. Zorkaya reflected on the imperfection of the definition of "documentary film", pointing to the affiliation of the film "Supreme Court" to the category of "high screen publicity", which, turns out, today is quite capable of rivaling the artistic narrative. Ultimately, Herz Frank himself did not see the border between image and information content in documentary films. 
He concluded: "The documentary filmmaker has the view of an artist who should not distort this reality, but must see in his own way" [Frank, 2004].

\section{Results and Discussion}

Summing up, one should, first of all, emphasize the significantly increased public interest in the genre of non-fiction in recent years and, as a result, interest in this phenomenon on the part of scientific communities in Russia and abroad. Hence our attention to this topic, due also to the fact that many features of the direction of "new journalism" appeared in the USA in the early 60's of last century, presented by the names of Truman Capote, Hunter Thompson, Norman Mailer, Tom Wolfe and others, and associated with them the genre of non-fiction, are found in the tradition of domestic court essays as a genre of fiction publicistics, and in the brightest examples of our documentary. The nature of the non-fiction genre is still not clear. There are discrepancies in the understanding of both the term and the mechanisms of formation of the phenomenon behind it as a hybrid, synthetic meta genre; there are difficulties in determining the ways of combining the figurative and life principles in it; there are disputes about the recognition and non-recognition of fiction and speculation within it; the methods of its analysis and criteria for assigning different works to it have not been developed. Through an interdisciplinary approach and a close study of the scientific literature on the topic, we have found a diversity of perspectives on the subject of our research from representatives of different sciences, such as: literature, linguistics, journalism, screen art theory and media, including film and television. Different scientists treat non-fiction differently, without achieving a holistic understanding of the creative world of the work.

Taking the genre of "narrative non-fiction", close in content to "narrative publicistics", or "fiction publicistics", which allow us to construct stories about real events with the help of artistic imagery, we offered our own perspective on things, moving away from the mechanical connection of journalism and literature as holistic structures. This led us to understand the traditional for the Russian practice of "narrative non-fiction" not as a hybrid of journalism and literature, existing as independent forms of creative activity, but as a combination within a single narrative structure of two equal components - the life foundation and artistic way of mastering reality.

Further, we addressed the problem not only in relation to the verbal but also to the audiovisual narrative. Namely: in relation to our domestic practice 
of certain forms of verbal language carried out in the genre of true crime (real crime). This refers to the richest experience of the Soviet judicial essay, on the one hand, and screen documentary, on the other. At the same time, it was shown that this experience clearly differs for the better from the practice of domestic television related to programs on criminal topics.

Research on these areas should certainly be pursued both theoretically and in terms of empirical observation and analysis. In the future it would be interesting to get acquainted with the newest foreign scientific literature concerning both traditions of "new journalism" and world practice of non-fiction in the genre of true crime.

\section{Conflict of Interest}

The authors have no conflict of interest to declare.

\section{References:}

1. Literary Journalism: A New Collection of the Best American Nonfiction. N. Sims, M. Kramer, Ballantine Books, N. Y. (1995).

2. J. Hartsock. A History of American Literary Journalism. The Emergence of a Modern Narrative Form. University of Massachusetts Press, Amherst (2000).

3. R.S. Boynton. The New New Journalism: Conversation with America's Best Nonfiction Writers on Their Craft. Vintage Books, N. Y. (2005).

4. M.E. Novoselova. Novyj zhurnalizm: ot istokov do nashih dnej [New journalism: from its origins to the present day]. Filologicheskie nauki. Voprosy teorii i praktiki [Philological science. Questions of theory and practice]. Gramota, Tambov: Vol.1. № 10 (2017), pp. 45-51.

5. L. Gutkind. You Can't Make This Stuff Up: The Complete Guide to Writing Creative Nonfiction - from Memoir to Literary Journalism and Everything in Between. Da Capo Lifelong Books, Boston (2012).

6. Telling True Stories: A Nonfiction Writers' Guide from the Nieman Foundation at Harvard University. M. Kramer, W. Call, Plume, N. Y. (2007).

7. J. Hart. Storycraft: The Complete Guide to Writing Narrative Nonfiction (Chicago Guides to Writing, Editing, and Publishing). University of Chicago Press, Chicago (2011).

8. E. A. Savel'eva. Mezhdu literaturoj i zhurnalistikoj: non-fikshn v zarubezhnom i otechestvennom literaturovedenii [Between literature and journalism: non-fiction in foreign and domestic literary studies]. Vestnik Cherepoveckogo gosudarstvennogo universiteta [Bulletin of the Cherepovets state University]. № 2 (83) (2018), pp. 85-91. 
9. O. O. Nesmelova, Zh. G. Konovalova. Novyj zhurnalizm: teoreticheskie principy $i$ ih hudozhestvennoe voploshchenie [New journalism: theoretical principles and their artistic implementation]. Uchenye zapiski Kazanskogo universiteta [Scientific notes of Kazan University]. Vol. 153, book 2 (2011), pp. 245-258.

10. Estetika zhurnalistiki [The aesthetics of journalism]. Alethea, Saint Petersburg (2018).

11. Novaya zhurnalistika i Antologiya novoj zhurnalistiki [New journalism and anthology of new journalism]. T. Vulfa i E. U. Dzhonsona, Saint Petersburg. (2008). URL: http: coollib.com/b/195937/read (Accessed 25.06.2020).

12. M.E. Novoselova. Novyj zhurnalizm: ot istokov do nashih dnej [New journalism: from its origins to the present day]. Filologicheskie nauki. Voprosy teorii i praktiki [Philological science. Questions of theory and practice]. Gramota, Tambov. Vol.1. № 10 (2017), pp. 45-51.

13. G. M. Kazakova. Non-fikshn v sovremennoj knizhnoj kul'ture [Non-fiction in modern book culture]. Vestnik Chelyabinskoj gosudarstvennoj akademii kul'tury $\mathrm{i}$ iskusstv [Bulletin of the Chelyabinsk state Academy of culture and arts]. № 3 (47) (2016), pp. 7-12.

14. V.A. Agranovskij. Radi edinogo slova. Zhurnalist o zhurnalistike [For a single word. Journalist about journalism]. Moscow (1978). URL: http: search.rsl.ru>ru/ record/01007618817 (Accessed 20.08.2020).

15. O. I. Desyukevich. Konceptual'naya publicistika Svetlany Aleksievich: kristallizaciya zhanra [Svetlana Alexievich's conceptual journalism: crystallization of the genre]. Media-lingvistiks. https://medialing.ru/konceptualnaya-publicistika-svetlany-aleksievich-kristallizaciya-zhanra/.(Accessed 20.08.2020)

16. G. V. Krasnov. Ocherk - malaya povestvovatel'naya forma [Essay is a small narrative form.] Vestnik Chuvashkogo. Universiteta [Bulletin of the Chuvash University]. № 6 (2006), pp. 260-265. https://cyberleninka.ru/article/n/ocherk-malaya-povestvovatelnaya-forma (Accessed: 15.08.2020).

17. D. L. Bykov. Trumen Kapote. Diletant. № 3 (39) (2015). http: https://bookskeeper.ru/jurnaly/gumanitarnye/34875-diletant-3-2015.html (Accessed 5.08.2020).

18. V.V. Horol'skij. "Novyj zhurnalizm v SShA": problema fakta i domysla ["New journalism in the USA": the problem of fact and speculation]. Nauchnye vedomosti, ser Gum nauki [Scientific Bulletin, Humanities series], № 12 (131) (2012), pp. 146-151.

19. Zh. G. Konovalova. Kinematograficheskie priemy v dokumental'nom romane T. Kapote "Hladnokrovnoe ubijstvo" [Cinematic techniques in T. Capote's 
documentary novel "Cold-blooded murder"]. Uchen. Zap. Kazan. Un-ta [Scientific notes of Kazan University]. Vol 155, book 2 (2013), pp. 197-206.

20. H. Frank. Smotret' i videt' [Watch and see]. Iskusstvo kino [Art of cinema], № 3 (2004). http: kinoart.ru/a rchive/2004/03/n3-article19 (Accessed 20.08.2020).

21. N. M. Zorkaya. "Vysshij sud" v rajonnom sude. Opyt vstrechi kinoveda s sovremennym neigrovym kino ["Higher court" in the district court. Experience of meeting a film critic with modern non-fiction cinema].Vzryv. Bytie i byt dokumental'nogo kino v konce vos'midesyatyh [Explosion. Life of documentary films in the late eighties.]. Moscow (1991), pp. 30-48.

DOI 10.15826/B978-5-7996-3081-2.37

\title{
Interaction "Journalist — Robot Journalist": Communicative Advantages and Social Responsibility
}

\section{Zvereva Ekaterina}

Derzhavin Tambov State University, Tambov, Russia

Katya9_2001@mail.ru

\begin{abstract}
The relevance of the study is based on the statement of the problem of "replacing" journalists with robots and the prospects for the disappearance of the profession. The purpose of the work is to analyze the communication advantages and assess the menace of using robotic journalism based on examples of Russian and foreign media during the period 2016-2020. In the work, such concepts are used to avoid an extended interpretation of the notion "artificial intelligence" in journalism; the problem of social responsibility of journalists is raised when creating content using artificial intelligence technologies.
\end{abstract}

Keywords: artificial intelligence, media communication, mass media, robotic journalism

\section{Introduction}

Analysts at Yandex in July 2020 conducted a study that included an analysis of headlines about artificial intelligence (AI) news from 2010 to 2020, and found that the number of such news has doubled [Russians still consider AI 